\title{
Distribution of Seven N-Nitrosamines in Food
}

\author{
Jong-eun Park', Jung-eun Seo', Jee-yeon Lee ${ }^{2}$ and Hoonjeong Kwon ${ }^{1,3}$ \\ 'Department of Food and Nutrition, Seoul National University, Seoul, Korea \\ ${ }^{2}$ Bureau of Health Industry Policy, Korea Health Industry Development Institute, Cheongju, Korea \\ ${ }^{3}$ Research Institute of Human Ecology, Seoul National University, Seoul, Korea
}

(Received August 25, 2015; Revised September 13, 2015; Accepted September 16, 2015)

\begin{abstract}
$\mathrm{N}$-nitrosamines, which are classified as carcinogens by IARC and US EPA, can be easily found in various foods. They are reaction products between nitrogen oxide and secondary amines, but can also be generated during fermentation. Ever since the $1960 \mathrm{~s}$, when nitrite, used as a preservative in processed meats, was suspected to generate N-nitrosamines, the usage of the food additive has been debated. However, the benefit of nitrite in food supply could not be ignored and the risk-benefit analysis has become a key issue in the use of the additive. For a risk analysis, an accurate estimation of the hazardous material is necessary; therefore, analytical methods for nitrosamines have continuously evolved from the 1950s. Solid supported liquid-liquid extraction and solid phase extractions have replaced the distillation for the clean-up steps, and tandem mass spectrometry is employed for higher selectivity and sensitivity. In the present study, for a better estimation of N-nitrosamine intake, the total diet study samples were prepared for the Nnitrosamines analysis. In order to obtain the most sensitive results, a partial preparation procedure was developed and modified for different food matrices. Among seven N-nitrosamines (N-nitrosodimethylamine, N-nitrosomethylethylamine, N-nitrosodiethylamine, N-nitrosodibutylamine, N-nitrosopiperidine, $\mathrm{N}$-nitrosopyrrolidine, and N-nitrosomorpholine) analyzed in the present study, N-nitrosodiethylamine has shown the highest detection rate in agricultural foods, while $\mathrm{N}$-nitrosodimethylamine has appeared most frequently in livestock and fishery food products. The concentration of N-nitrosodimethylamine was the highest in seasoning.
\end{abstract}

Key words: N-nitrosamine, Total Diet Study

\section{INTRODUCTION}

$\mathrm{N}$-nitrosamines have been found in air, water, foods, cosmetics, tobacco, and packing materials (1). N-nitrosamines have been an issue due to nitrite which was added to prevent the growth of Clostridium botulinum in processed

Correspondence to: Hoonjeong Kwon, Research Institute of Human Ecology, Seoul National University, 1 Gwanak-ro, Gwanakgu, Seoul 151-742, Korea

E-mail: hjkwon@snu.ac.kr

Abbreviation: NDMA, N-nitrosodimethylamine; NMEA, N-nitrosomethylethylamine; NDEA, N-nitrosodiethylamine; NDBA, N-nitrosodibutylamine; NPIP, N-nitrosopiperidine; NPYR, Nnitrosopyrrolidine; NMOR, N-nitrosomorpholine; NDPhA, N-nitrosodiphenylalanine; NPRO, N-nitrosoproline; NSAR, N-nitrososarcosine.

This is an Open-Access article distributed under the terms of the Creative Commons Attribution Non-Commercial License (http:// creativecommons.org/licenses/by-nc/3.0) which permits unrestricted non-commercial use, distribution, and reproduction in any medium, provided the original work is properly cited. meats. For this reason, high concentrations of nitrosamines have been reported in bacon, sausage, and ham in high rate (2), while meats that did not go through processing showed low, if any, amount of nitrosamines. N-nitrosamines were also reported in salted fish, beer, and water (3).

$\mathrm{N}$-nitrosamines are formed by reactions of organic amines and their derivatives with nitrosating compounds; however, most stable nitrosamines are formed from secondary amines (4). Since these precursors can, in turn, be generated from pesticides and herbicide, as well as nitrogen fertilizers, $\mathrm{N}$-nitrosamines can be found as contaminants in various foods. The chemical reactions in which N-nitrosamines are formed from various sources are well reviewed by Rostkowska et al. (4). In foods, nitrosamines are formed by reactions of nitrogen oxide with amines. Nitrite in food, whether reduced from nitrate fertilizer or added as a preservative, is hydrogenated to hydronitrogenoxide $\left(\mathrm{H}_{2} \mathrm{NO}_{2}^{+}\right)$in acidic condition (Fig. 1) (4). The resulting hydronitrogenoxide $\left(\mathrm{H}_{2} \mathrm{NO}_{2}^{+}\right)$reacts with another molecule of nitrite to form nitrogen anhydride after dehydration. Nitrogen anhydride donates nitroso group to the amines in food to produce $\mathrm{N}$ - 
(A)

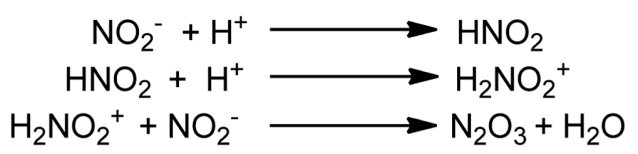

(B)

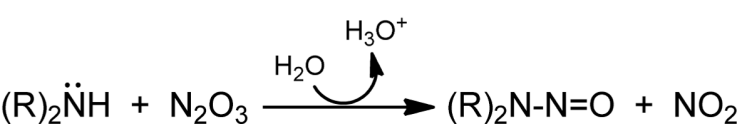

Fig. 1. N-nitrosamine formation (modified from Rostkowska et al. (4)). (A) Formation of a nitrous anhydride from a nitrite (B) nitrosation from a nitrous anhydride and an amine.

nitrosamines (5). Secondary amine can form stable nitrosamine, while nitrosamines derived from primary amine break down quickly; it is also known that tertiary amine can hardly form nitrosamine (6). In spinach, cabbage, and other vegetables, nitrate has been reported to be reduced to nitrite by microorganisms (3). The nitrosating reaction may also occur in the stomach by the reaction of nitric oxide from nitrite or nitrate with amines in acidic condition. The optimum $\mathrm{pH}$ of the reaction is 3 to 4 and synthesis of the nitrosamines in the rabbit, cat, and human stomach from the precursors has been reported $(7,8)$.

$\mathrm{N}$-nitrosodimethylamine in beer has been an issue in Germany (9). It was shown that during the kilning (drying of malt) procedure of beer production, nitrogen oxide from combustion would react with amines like gramine and hordenine in the malt to form NDMA. To reduce nitrosation during kilning, sulfur dioxide or indirect-fire kilns were used in the malting industry (9). The possibility of nitrosamine formation and contents of nitrosamine were high in the past; however, N-nitrosamines in beer have gradually decreased these days because of the efforts poured in to inhibit nitrosation by controlling the brewing procedures (10). It has also been suggested that bacterial biochemical pathway may contribute to the nitrosamine formation during fermentation. Microorganisms reduce nitrate to nitrite, degrade proteins to secondary amines, and create an appropriate environment (slightly acidic). Microorganism in the wild, including bacteria and yeasts, utilized nitrite and nitrate for growth and generate the nitrosating compound in the process. Decarboxylation of amino acids by a microbial enzyme is a well-known reaction in fermentation and an important pathway to generate precursors of nitrosamines. Microbial polyamine synthesis following decarboxylation of amino acids provides amine precursors for cyclic Nnitrosamines (N-nitrosopiperidine and N-nitrosopyrrolidine) (11).

Nitrosamine detected in water has been considered to be a disinfection by-product; afterwards, it has been suggested that the reaction between dimethylamine, a contaminant from wastewater, and monochloramine may form N-nitrosodimethylamine (NDMA). Monochloramine is used instead of chlorine to regulate halogenated by-products (12). In the 1960s, it was revealed that nitrite which was used to preserve Pacific herring was related to ruminants' liver disease. As N-nitrosodimethylamine (NDMA) was separated from the Pacific herring, the concerns about the nitrosamines in foods have been increased (12). Nitrosamines that have been found in foods are NDMA (N-nitrosodimethyamine), NDEA (N-nitrosodiethylamine), NDBA (N-nitrosodibutylamine), NPIP (N-nitrosopiperidine), NPYR (N-nitrosopyrrolidine), NMOR (N-nitrosomorpholine), NDPhA (Nnitrosodiphenylamine), NPRO (N-nitrosoproline), and NSAR (N-nitrososarcosine) (13). In the 1950s, carcinogenicity studies disclosed that nitrosamine could induce cancer in rats. NDMA and NDEA were classified as 2A (probably carcinogenic to human), NMEA, NDBA, NPIP, NPYR, NMOR, and NSAR were classified as $2 \mathrm{~B}$ (possibly carcinogenic to human) by the International Agency for Research on Caner (IARC) (14). However, NPRO and N-nitrosodiphenylalnine (NDPhA) were classified as 3 (not classifiable as to its carcinogenicity to humans).

It has been reported that the contents of nitrosamines changed with respect to cooking methods, temperature, time, moisture of food, or fat composition (15). Nitrosamine formation in bacon was tested with several cooking conditions, such as fried, baked, broil, and microwave cooking. In fried and baked bacons, up to $35 \mathrm{ppb}$ of NPYR was detected, while none was detected in raw bacon. Microwave cooking generates only $3 \mathrm{ppb}$ of NPYR. According to the results, cooking temperature of $99 \sim 185^{\circ} \mathrm{C}$ was most effective in accelerating nitrosation. At temperatures below $100^{\circ} \mathrm{C}$, no NPYR or NPRO was detected (16). Furthermore, it was revealed that fat in bacon also had an effect on NPYR and NDMA contents. Bacon rashers were separated with lean and fat components to test the impact of fat. When fried separately using a thermostatically controlled electric frying pan at $178 \pm 3^{\circ} \mathrm{C}$ for $12 \mathrm{~min}$, fried whole rasher bacon showed $15.6 \mathrm{ppb}$ (mean) of NPYR and 6.7 ppb (mean) of NDMA. Fat component of bacon showed $3.7 \mathrm{ppb}$ of NPYR and $14.9 \mathrm{ppb}$ of NDMA mean, while lean bacon showed $3 \mathrm{ppb}$ of NPYR and $2.6 \mathrm{ppb}$ of NDMA. Higher amounts of both nitrosamines were detected in the fat portion of fried bacon, as compared to the lean portion (17). Also, in the case of frankfurter sausage, NDMA increased during cooking (18).

The present study focused on seven most frequently reported N-nitrosamines in food, namely, NDMA, NMEA, NDEA, NDBA, NPIP, NPYR and NMOR. To obtain a better estimation of nitrosamine exposures, a total of 387 total diet study samples which reflects ready to fork foods were employed. To cover most of the food items in the Korean diet, an analytical procedure was developed to cover variety of food matrices. Finally, for a better understanding of nitrosamine sources within various foods, the results are presented in comparison with the reported values. 


\section{MATERIALS AND METHODS}

Reagents. All reagents used in the experiments were $\mathrm{GC}$ or pesticide residue grade. C-18 cartridge $(500 \mathrm{mg}, 6$ $\mathrm{mL})$ and Florisil $(1 \mathrm{~g}, 6 \mathrm{~mL})$ were purchased from Waters (Milford, USA). Aluminum oxide (basic) was purchased from Sigma Aldrich (St Louis, USA). Extrelut NT was purchased from Merck (Darmstadt, Germany). EPA nitrosamine mixture was purchased from Sigma Aldrich. Another set of standard and deuterated internal standards were purchased from Chiron. Calibration curve was obtained from the standard solution which went through the experimental procedures.

Samples. A total of 387 diet study samples were used in this study. The foods were chosen based on a national nutrition survey over a 3 year period. Seven largest cities in Korea were selected based on population and samples purchased from these seven cities were pooled. Thus, in this study, only one composite sample was subject to analysis for each food item. The samples were homogenized for the experiments if needed. All samples were provided by Korea Heath Industry Development Institute.

Partial purification of food samples. The partial purification procedure was based on the method reported else- where $(19,20)$, with modifications depending on food matrices (Table 1). The basic procedure is as follows: Deuterated internal standards and $5 \mathrm{~mL}$ of $0.1 \mathrm{~N}$ sodium hydroxide solutions were added to $5 \mathrm{~g}$ of sample in polypropylene conical tube. After vortexing, the solid sample was mixed with $6 \mathrm{~g}$ of prewashed Extrelut and loaded on to a column $(3.7 \mathrm{~cm} \times 20 \mathrm{~cm})$. In the case of liquid samples, the sample was directly loaded onto the column preloaded with $6 \mathrm{~g}$ of Extrelut. The sample tube was washed twice with $5 \mathrm{~mL}$ of Dichloromethane (DCM) : n-hexane $(9: 1 \mathrm{v} /$ v) and the washing solvents were poured to the column. The fraction containing nitrosamines was eluted with $40 \mathrm{~mL}$ of DCM : n-hexane $(9: 1 \mathrm{v} / \mathrm{v})$. After the concentration under the reduced pressure, the eluate was loaded onto Florisil cartridge prewashed with $6 \mathrm{~mL}$ of $\mathrm{n}$-hexane. The vial was washed three times with $1 \mathrm{~mL}$ of $\mathrm{n}$-hexane and added to the cartridge. Lipophilic substances were washed out of the cartridge with $3 \mathrm{~mL}$ of $\mathrm{n}$-hexane and the relatively polar nitrosamine fraction was eluted with $6 \mathrm{~mL}$ of $\mathrm{DCM}: \mathrm{MeOH}(95: 5 \mathrm{v} / \mathrm{v})$. Following the concentration step, the volume of the eluate was adjusted to $1 \mathrm{~mL}$ with DCM.

Fat-rich (food items containing over $10 \%$ of fat): The solid supported extraction using Extrelut was not applicable to the food items with large amount of fat. Since the nitrosamines are relatively polar organic compounds, a liq-

Table 1. Summary of analytical procedures for N-nitrosamine in various food matrices

\begin{tabular}{|c|c|c|c|c|}
\hline \multirow[b]{3}{*}{ Procedures* } & \multicolumn{4}{|c|}{ Food Matrices } \\
\hline & \multirow{2}{*}{$\frac{\text { Fatless }(<10 \% \text { lipid })}{\text { Milk, Apple juice, Porridge }}$} & \multirow{2}{*}{$\frac{\text { Alcohol }}{\text { Wine, soju }}$} & \multicolumn{2}{|c|}{ Fat-rich (>10\% lipid) } \\
\hline & & & Beef & Corn oil \\
\hline & \multicolumn{4}{|c|}{ Sample $5 \mathrm{~g}$} \\
\hline Deuterated Internal standards. ${ }^{*}$ & 3 & 3 & 7 & 7 \\
\hline $\mathrm{NaOH}$ & $\bigcirc$ & $\bigcirc$ & $\times$ & $\times$ \\
\hline \multirow{2}{*}{$\begin{array}{l}\text { Liquid Liquid } \\
\text { Extraction }\end{array}$} & \multirow{2}{*}{$x$} & \multirow{2}{*}{$x$} & $\begin{array}{l}\text { Acetone }: \mathrm{ACN}=1: 1 \\
(40 \mathrm{~mL})\end{array}$ & $\begin{array}{c}\text { Acetone }: \text { water }=3: 1 \\
(40 \mathrm{~mL})\end{array}$ \\
\hline & & & \multicolumn{2}{|c|}{$\begin{array}{l}\text { Centrifugation }\left(3500 \mathrm{rpm}, 240 \mathrm{sec}, 4^{\circ} \mathrm{C}\right) \text {, } \\
\text { Store at }-80^{\circ} \mathrm{C} \text { for } 35 \mathrm{~min} \text {, Centrifugation }\end{array}$} \\
\hline Concentration & $\times$ & $\times$ & Reduced pressure & $\mathrm{N}_{2}$ \\
\hline $\begin{array}{l}\text { Solid Supported Extraction } \\
\text { (Extrelut) }\end{array}$ & $\bigcirc$ & $\bigcirc$ & $\times$ & $\bigcirc$ \\
\hline Concentration & Reduced pressure & Reduced pressure & $\times$ & Reduced pressure \\
\hline SPE & Florisil & $\times$ & C-18 \& alumina & $\times$ \\
\hline Concentration & $\mathrm{N}_{2}$ & $\times$ & Reduced pressure & $\times$ \\
\hline Final vol. and solvent & $\begin{array}{c}1 \mathrm{~mL} \\
\text { Dichloromethane (DCM) }\end{array}$ & $1 \mathrm{~mL} \mathrm{DCM}$ & $1 \mathrm{~mL}$ Acetonitrile & $0.5 \mathrm{~mL} \mathrm{DCM}$ \\
\hline
\end{tabular}

\footnotetext{
* See text for details.

${ }^{\ddagger} 3$ internal standards: NDEA-d10 for NDMA, NDEA, and NMEA; NPYR-d8 for NPIP, NPYR, and NMOR. NDBA-d18 for NDBA, 7 internal standards: deuterated counterparts for each $\mathrm{N}$-nitrosamines.
} 
Table 2. Instrument method of GC-PCI-MS/MS

\begin{tabular}{|c|c|}
\hline Column & $\begin{array}{l}\text { Pre: DB-5ms }(5 \mathrm{~m} \times 0.53 \mathrm{~mm} \text { I.D., } 0.25 \mu \mathrm{m} \mathrm{df}) \\
\text { Main: DB-wax }(60 \mathrm{~m} \times 0.25 \mathrm{~mm} \text { I.D., } 0.5 \mu \mathrm{m} \mathrm{df})\end{array}$ \\
\hline Flow rate & $\mathrm{He}, 2.0 \mathrm{~mL} / \mathrm{min}$ \\
\hline Inject temp. & $220^{\circ} \mathrm{C}$ \\
\hline Inject volume & Fat less $2 \mu \mathrm{L} /$ Fat-rich solid $4 \mu \mathrm{L}$ \\
\hline Oven & $\begin{array}{l}50^{\circ} \mathrm{C}(1 \mathrm{~min}, \text { hold }) \rightarrow 20^{\circ} \mathrm{C} / \mathrm{min} \rightarrow 120^{\circ} \mathrm{C}(0 \mathrm{~min}) \rightarrow 5^{\circ} \mathrm{C} / \mathrm{min} \\
\rightarrow 200^{\circ} \mathrm{C}(0 \mathrm{~min}) \rightarrow 20^{\circ} \mathrm{C} / \mathrm{min} \rightarrow 220^{\circ} \mathrm{C}(5 \mathrm{~min}, \text { hold })\end{array}$ \\
\hline Transfer line temperature & $240^{\circ} \mathrm{C}$ \\
\hline Source temperature & $150^{\circ} \mathrm{C}$ \\
\hline Reagent gas & Ammonia $\left(\mathrm{NH}_{3}\right)$ gas (Flow: $\left.2 \mathrm{~mL} / \mathrm{min}\right)$ \\
\hline Collision gas & Ar (cell pressure: $60 \mathrm{~Pa}$ ) \\
\hline
\end{tabular}

uid-liquid extraction was employed for fat-rich food samples. Acetone-water $(3: 1)$ or acetone-acetonitrile mixture satisfied the terms. After the addition of internal standard, $5 \mathrm{~g}$ of fat containing samples were extracted with a $40 \mathrm{~mL}$ of acetone and acetonitrile mixture $(50 \% \mathrm{v} / \mathrm{v})$. For extraction, the tube containing solvent and sample was shaken thoroughly and centrifuged at $3000 \mathrm{rpm}$ at $4^{\circ} \mathrm{C}$ for $240 \mathrm{sec}$ to separate phases. The mixture was stored at $-80^{\circ} \mathrm{C}$ for $30 \mathrm{~min}$ to help separate the phases. After following another centrifugation, supernatant (acetone-acetonitrile phase) was transferred to a glass vial. The remaining fat in the supernatant was removed by alumina-C 18 resin. Two $\mathrm{g}$ of basic aluminum oxide aluminum oxide was overlaid on top of $\mathrm{C}$ 18 SPE cartridge and then prewashed with $25 \mathrm{~mL}$ of acetonitrile. The concentrated supernatant was passed through the alumina-C18 cartridge. A $25 \mathrm{~mL}$ of acetonitrile was used to wash the cartridge. Unbound and washing fractions were combined and concentrated. The final volume was adjusted to $1 \mathrm{~mL}$ with acetonitrile.

Alcoholic beverages: The method for alcoholic beverage followed the basic procedures except for the final Florisil - SPE step.

Oil: Relatively pure oil samples were extracted with a $40 \mathrm{~mL}$ of acetone-water $(3: 1)$ mixture. The acetone phase was removed after solidification of the oil phase at $-80^{\circ} \mathrm{C}$ for $30 \mathrm{~min}$, as in the fat-rich sample described above. After concentration, the extract was subjected to solid supported extraction with Extrelut, as described in the basic procedure. The eluate was concentrated under the nitrogen gas without further purification and the final volume was adjusted to $0.5 \mathrm{~mL}$ with the DCM.

Internal standards. For the fat-rich samples and oils, deuterated internal standards were used for each N-nitrosamine. However, for the fatless samples, for economical reason, NDEA-d10 was used for NDMA, NDEA, and NMEA; NPYR-d8 was used for NPIP, NPYR, and NMOR. NDBAd18 was employed for NDBA, separately. All internal stan-
Table 3. Selected ions for seven $\mathrm{N}$-nitrosamines

\begin{tabular}{lcccc}
\hline \hline Compounds & $\begin{array}{c}\text { Retention } \\
\text { time }(\mathrm{min})\end{array}$ & $\begin{array}{c}\text { Precursor } \\
\text { ion }(\mathrm{m} / \mathrm{z})\end{array}$ & $\begin{array}{c}\text { Product } \\
\text { ion } 1(\mathrm{~m} / \mathrm{z})\end{array}$ & $\begin{array}{c}\text { Product } \\
\text { ion } 2(\mathrm{~m} / \mathrm{z})\end{array}$ \\
\hline NDMA & 9.66 & 92 & 75 & 43 \\
NMEA & 10.45 & 106 & 89 & 61 \\
NDEA & 11.03 & 120 & 103 & 75 \\
NDBA & 17.41 & 176 & 159 & 103 \\
NPIP & 18.11 & 132 & 115 & 69 \\
NPYR & 18.64 & 118 & 101 & 55 \\
NMOR & 19.55 & 134 & 87 & $*$ \\
\hline
\end{tabular}

*Product ion 2 of NMOR could not be measured due to interference.

dards were used in this experiment at concentration of $5 \mu \mathrm{g} / \mathrm{kg}$.

GC-PCI-MS/MS analysis. The extract was analyzed by gas chromatography-positive chemical ionization tandem mass spectrometer (GC-PCI-MS/MS) adopting ammonia gas as an ion source. DB-5ms $(5 \mathrm{~m} \times 0.53 \mathrm{~mm}$ I.D., $0.25 \mu \mathrm{m}$ df) precolumn was used with DB-wax $(60 \mathrm{~m} \times 0.25 \mathrm{~mm}$ I.D., $0.5 \mu \mathrm{m} \mathrm{df)} \mathrm{main} \mathrm{column.} \mathrm{Injector} \mathrm{temperature} \mathrm{was}$ $220^{\circ} \mathrm{C}$ and transfer line temperature was $240^{\circ} \mathrm{C}$. Source temperature was $150^{\circ} \mathrm{C}$. Oven temperature was increased from $50^{\circ} \mathrm{C}$ to $220^{\circ} \mathrm{C}$ and the total run time was $26.5 \mathrm{~min}$ for each sample (Table 2). The ions selected for seven N-nitrosamines are listed in Table 3.

\section{RESULTS AND DISCUSSION}

The method was validated according to suggestions of Myeong's report (21). Calibration curves, obtained by subjecting standard compounds to the analytical procedures, showed a correlation coefficient higher than 0.99 for all nitrosamines in all matrices. The method detection limit (MDL) values ranged from 0.10 to $0.30 \mu \mathrm{g} / \mathrm{kg}$. These MDL values were similar to the instrumental LOD values reported 
in the literature $(28,34)$. Using three concentrations of standard solutions, recovery was measured in all matrices. The recoveries for all seven nitrosamines in different matrices ranged between 80 to $120 \%$, i.e. within the acceptable range provided by CODEX (21). Relative standard deviation, measured with spiked samples in milk and rice soup, was below $14 \%$, for both intraday and inter-day measurements in three concentration levels. The results were within the criteria of CODEX.

NDMA and NDEA were most frequently detected in agricultural food products (Table 4). Kim and Yoon reported a high concentration of nitrate in some of the fruits (22) and this nitrate may have been reduced to nitrite and contribute to the formation of NDMA. A small amount of nitrosamine was detected in tofu, mung-bean jelly, acorn jelly and buckwheat jelly. NMOR $0.15 \mu \mathrm{g} / \mathrm{kg}$ was the maximum detected content. $2.64 \mu \mathrm{g} / \mathrm{kg}$ of NDMA and $2.05 \mu \mathrm{g} / \mathrm{kg}$ of NDEA were detected separately in the kimchi group. Therefore, it can be concluded that NDMA was either formed during fermentation and/or by reactions between nitrite (from nitrate) and amines. The content of NDMA in kimchi was ca. 3 times lower than in Kim et al.'s results (23).

Less than $1 \mu \mathrm{g} / \mathrm{kg}$ was detected in the group of rice cake, flour, bread, doughnut, pickled vegetable, and croquette in all nitrosamines. NDMA ranged from ND to $1.71 \mu \mathrm{g} / \mathrm{kg}$ was detected in the cereal, potatoes, and beans group; other nitrosamines were detected in the quantities below $0.76 \mu \mathrm{g} /$ $\mathrm{kg}$. The maximum of $6.1 \mu \mathrm{g} / \mathrm{kg}$ and $4.9 \mu \mathrm{g} / \mathrm{kg}$ NDMA was detected in fresh vegetables and mushrooms, respectively, as well as the maximum of $6.11 \mu \mathrm{g} / \mathrm{kg}$ of NDBA in mushrooms. The study has demonstrated higher nitrosamine contents in vegetables than those previously reported in the literature (24). Since soil microorganisms are known to contribute to nitrosamine formation and given that nitrate contents in vegetables can also contribute (10), the fluctuation of the nitrosamine contents can be expected. It is notable that NDMA and NDEA were detected in the maximum of 2.95 and $2.22 \mu \mathrm{g} / \mathrm{kg}$ respectively, in snack samples. Other nitrosamines were relatively low.

NDMA, NDBA, and NMOR were detected in fishery products, but on a very low level (Table 5). Milk and milk products did not show remarkable contents of any of the tested nitrosamines. NDMA of cheese showed $0.72 \mu \mathrm{g} / \mathrm{kg}$ and the others, such as cake and ice cream, showed less than $0.56 \mu \mathrm{g} / \mathrm{kg}$ (Table 6). The exception was freshwater eel which showed 3.93 to $4.18 \mu \mathrm{g} / \mathrm{kg}$ of NDMA. Furthermore,

Table 4. N-nitrosamine contents in agricultural products $(\mu \mathrm{g} / \mathrm{kg})$

\begin{tabular}{|c|c|c|c|c|c|c|c|c|c|c|}
\hline Product & $\begin{array}{l}\text { The number } \\
\text { of samples }\end{array}$ & NDMA & NDEA & NDBA & NPYR & NPIP & NMOR & NMEA & Total & Ref \\
\hline Cereals and potato & $22^{\#}$ & ND-1.71 & ND-0.72 & ND-0.76 & ND-0.38 & ND-0.15 & ND-0.18 & ND & & 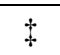 \\
\hline Cereals & 8 & ND-0.41 & - & - & - & - & - & - & & 30 \\
\hline Kind of flours & $5^{\#}$ & ND-0.92 & ND-0.66 & ND-0.19 & ND & ND & ND & ND & & 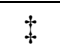 \\
\hline Pickled vegetable & $4^{\#}$ & ND-0.42 & ND-0.26 & ND-0.25 & ND-0.2 & ND & ND-0.66 & ND & & $\$$ \\
\hline \multirow{2}{*}{ Kimchi } & $11^{\#}$ & $0.13-2.64$ & ND-2.05 & ND-0.22 & ND & ND-0.26 & ND & ND & & 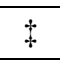 \\
\hline & 7 & $0.8-6.9$ & - & - & - & - & - & - & & 23 \\
\hline \multirow{2}{*}{ Fresh vegetables } & 6 & $<3.3$ & - & - & - & - & - & - & & 30 \\
\hline & $53^{\#}$ & ND-6.01 & ND-1.53 & ND-1.61 & ND & ND-0.67 & ND-0.4 & ND & & $t$ \\
\hline Frozen vegetable & 1 & - & 3.9 & - & - & 1.7 & - & - & & 30 \\
\hline Mushroom & $7^{\#}$ & ND-4.9 & ND-0.62 & ND-6.11 & ND & ND & ND & ND & & 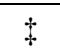 \\
\hline Rice cake & $11^{\#}$ & ND-0.8 & ND-0.23 & ND-0.46 & ND & ND & ND & ND & & 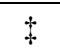 \\
\hline Fruit & $29^{\#}$ & ND-6.21 & ND-0.60 & ND-1.03 & ND & ND & ND-0.3 & ND & & + \\
\hline Tofu & $3^{\#}$ & ND & ND-0.2 & ND & ND & ND & ND & ND & & $\ddagger$ \\
\hline Vegetable jelly & $3^{\#}$ & ND & ND-0.11 & ND & ND & ND & ND-0.15 & ND & & $t$ \\
\hline $\begin{array}{l}\text { Bread, croquette, } \\
\text { doughnut }\end{array}$ & $20^{\#}$ & ND-0.98 & ND-0.91 & ND-0.64 & ND & ND-0.22 & ND-0.29 & ND & & $\$$ \\
\hline Noodle & $9^{\#}$ & ND-0.72 & ND-2.81 & ND- 0.80 & ND & ND-0.11 & ND-0.12 & ND & & $\ddagger$ \\
\hline Snack & $17^{\#}$ & ND-2.95 & ND-2.22 & ND-1.63 & ND-0.66 & ND-0.39 & ND-0.62 & ND-0.24 & & + \\
\hline Beverage & $28^{\#}$ & ND-3.57 & ND-0.56 & ND & ND-0.47 & ND-0.22 & ND-0.26 & ND & & + \\
\hline Fruit juice & 8 & - & - & - & - & - & - & - & $<2.75-45.70$ & 31 \\
\hline
\end{tabular}

ND: Not detected, -: Not tested, + : present study, ${ }^{\#}$ : number of composite samples. 
Table 5. N-nitrosamine contents of in seafoods $(\mu \mathrm{g} / \mathrm{kg})$

\begin{tabular}{|c|c|c|c|c|c|c|c|c|c|c|}
\hline Product & $\begin{array}{l}\text { The number } \\
\text { of samples }\end{array}$ & NDMA & NDEA & NPYR & NPIP & NDBA & NMOR & NMEA & Total & Ref \\
\hline Tuna & $1^{\#}$ & 0.12 & ND & ND & ND & ND & ND & ND & & $\$$ \\
\hline Frog flounder, porgy & $2^{\#}$ & $0.3-0.72$ & ND-0.14 & ND & ND & ND & ND-0.53 & ND & & $t$ \\
\hline Harvest fish & $1^{\#}$ & $0.99-2.06$ & ND & ND & ND & ND & ND & ND & & $\ddagger$ \\
\hline Freshwater eel & $1^{\#}$ & $3.93-4.18$ & ND & ND & ND & ND & ND & ND & & + \\
\hline Shell fish & $5^{\#}$ & $0.21-1.35$ & ND & ND-0.14 & ND & ND & ND-0.19 & ND & & $\ddagger$ \\
\hline $\begin{array}{l}\text { Mullet, spoon } \\
\text { wormand short } \\
\text { arm octopus }\end{array}$ & $3^{\#}$ & ND & ND & ND & ND & ND & ND & ND & & + \\
\hline \multirow{2}{*}{ Salted fish } & 20 & $12.64-322.92$ & $7.65-50.27$ & - & - & - & - & - & $20.29-373.19$ & 32 \\
\hline & 10 & $0.2-2.13$ & - & - & - & - & - & - & $0.2-2.13$ & 28 \\
\hline Salted shell fish & 2 & $0.2-0.59$ & - & - & - & - & - & - & $0.2-0.59$ & 28 \\
\hline salted pollack roe & 3 & $0.2-4.08$ & - & - & - & - & - & - & $0.2-4.08$ & 28 \\
\hline Salted shrimp & 5 & ND-0.9 & - & - & - & - & - & - & & 28 \\
\hline \multirow{2}{*}{ Salted anchovy } & 6 & ND-1.2 & - & - & - & - & - & - & & 23 \\
\hline & 1 & - & - & $<0.02$ & $<0.01$ & - & - & - & & 24 \\
\hline Shellfish aekjeot & 3 & $<0.2$ & - & - & - & - & - & - & $<0.2$ & 28 \\
\hline Anchovy aekjeot & 6 & - & - & $<0.02$ & $<0.01$ & - & - & - & & 24 \\
\hline Shellfish aekjeot & 2 & $0.2-0.57$ & - & - & - & - & - & - & $0.2-0.57$ & 28 \\
\hline Crab stick & 18 & $0.2-9.36$ & - & - & $0.2-1.01$ & - & - & - & $0.2-9.36$ & 28 \\
\hline Fish cake & 28 & $0.2-6.44$ & $0.2-0.74$ & - & $0.2-0.80$ & - & - & - & $0.2-6.44$ & 28 \\
\hline Fish sausage & 16 & $0.2-2.71$ & - & - & - & - & - & - & $<0.2-2.71$ & 28 \\
\hline Fish & 33 & $0.04-3.5$ & $0.06-4.2$ & - & - & $0.11-5.3$ & - & - & & 30 \\
\hline
\end{tabular}

ND: Not detected, -: Not tested, $\$$ : present study, ${ }^{\#}$ number of composite samples.

Table 6. N-nitrosamine contents in milk and milk products $(\mu \mathrm{g} / \mathrm{kg})$

\begin{tabular}{|c|c|c|c|c|c|c|c|c|}
\hline Product & $\begin{array}{l}\text { The number } \\
\text { of samples }\end{array}$ & NDMA & NDEA & NDBA & NPYR & NPIP & NMOR & Ref \\
\hline \multirow{2}{*}{ Cheese } & $3^{\#}$ & ND-0.72 & ND & ND & ND & ND & ND & $\ddagger$ \\
\hline & 21 & $<0.04-3$ & $<0.06-4$ & - & - & $<0.09-2.6$ & - & 30 \\
\hline Milk and milk products & $4^{\#}$ & $\mathrm{ND}$ & ND & ND & ND & ND & ND & $\$$ \\
\hline Yogurt & $3^{\#}$ & ND & ND & ND & ND & ND & ND & 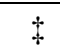 \\
\hline Cake & $5^{\#}$ & ND-0.56 & ND & ND-0.23 & ND & ND & ND-0.14 & $\ddagger$ \\
\hline Ice cream & $4^{\#}$ & ND-0.28 & ND & ND & ND & ND & ND & 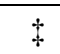 \\
\hline Powdered non-fat milk & 1 & $<0.05$ & - & - & $<0.08$ & $<0.08$ & - & 33 \\
\hline Powdered modified milk & 1 & $<0.05$ & - & - & $<0.08$ & $<0.08$ & - & 33 \\
\hline Dried milk powder & 5 & $<0.3$ & $<0.3$ & - & - & $<0.3$ & $<0.3$ & 20 \\
\hline
\end{tabular}

ND: Not detected, -: Not tested, $\$$ : present study, ${ }^{\#}$ : number of composite samples.

NDMA showed the highest detection rate in meat and meat products (Table 7 and 8). Dumplings which contain meat but also dozens of other ingredients, including seasoning, showed the highest amount of nitrosamines. In spite of the original concerns, NDMA ranged from 0.31 to $1.54 \mu \mathrm{g} / \mathrm{kg}$ in processed meats, such as sausages, hams, and bacons, which were lower than the contents found in vegetables or fruits. However, NPIP and NMOR were detected in pro- 
Table 7. N-nitrosamine contents in meat and meat products $(\mu \mathrm{g} / \mathrm{kg})$

\begin{tabular}{|c|c|c|c|c|c|c|c|c|c|}
\hline Product & $\begin{array}{l}\text { The number } \\
\text { of samples }\end{array}$ & NDMA & NDEA & NDBA & NPYR & NPIP & NMOR & NMEA & Ref \\
\hline Pork liver & $1^{\#}$ & $0.51-0.64$ & ND & ND & ND & ND & $0.21-0.29$ & ND & $\$$ \\
\hline Pork intestine and pork products & $5^{\#}$ & ND & ND & ND & ND & ND & ND & ND & $\$$ \\
\hline Pork flesh & $3^{\#}$ & ND & ND & ND & ND & ND & ND & ND & $\star$ \\
\hline Pork belly & $1^{\#}$ & $0.13-0.21$ & ND & ND & ND & ND & ND & ND & + \\
\hline Dumpling & $3^{\#}$ & $0.75-2.26$ & ND & ND & ND & ND & ND & ND & $\ddagger$ \\
\hline Beef intestine & $4^{\#}$ & ND-0.54 & ND & ND & ND & ND & ND-0.31 & ND & $\ddagger$ \\
\hline Beef and beef products & $9^{\#}$ & ND-0.48 & ND & ND-0.31 & ND-0.24 & ND & ND & ND & $\$$ \\
\hline Chicken & $7^{\#}$ & ND-0.52 & ND & ND-0.30 & ND & ND & ND & ND & $\ddagger$ \\
\hline Cow foot soup & $1^{\#}$ & $0.49-0.62$ & ND & ND & ND & ND & $0.16-0.29$ & ND & $\ddagger$ \\
\hline Pork meat, in salt & $2^{\#}$ & $0.08-0.28$ & $0.06-0.07$ & - & - & - & - & - & 30 \\
\hline Fat liver (duck) & $1^{\#}$ & 0.47 & 0.81 & - & 0.20 & 2.6 & 0.79 & - & 30 \\
\hline Duck & $1^{\#}$ & ND-0.13 & ND & ND & ND & ND & ND & ND & + \\
\hline Smoked pork brisket & 19 & $0.04-4.0$ & $0.06-9.5$ & $0.11-2.7$ & $0.16-11$ & $0.09-37$ & $0.19-2.1$ & - & 30 \\
\hline
\end{tabular}

ND: Not detected, -: Not tested, + : present study, ${ }^{\#}:$ number of composite samples.

Table 8. Contents of nitrosamine in processed meats $(\mu \mathrm{g} / \mathrm{kg})$

\begin{tabular}{|c|c|c|c|c|c|c|c|c|c|c|}
\hline Product & $\begin{array}{l}\text { The number } \\
\text { of samples }\end{array}$ & NDMA & NDEA & NDBA & NPYR & NPIP & NMOR & NMEA & Total & Ref \\
\hline Cooked sausages & $5^{\circ}$ & $0.33-0.5$ & 0.3 & - & - & $0.3-1.0$ & $<0.3$ & - & & 20 \\
\hline Fried and cooked sausage & 8 & $0.05-1.2$ & $0.03-5.1$ & $0.11-1.0$ & - & $0.09-0.22$ & - & - & & 30 \\
\hline \multirow{4}{*}{ Sausages } & $4^{\#}$ & $0.31-1.54$ & ND & ND & ND & ND-0.91 & ND & ND & & $t$ \\
\hline & $5^{\circ}$ & $0.04-4.5$ & $0.02-7.9$ & $0.11-1.0$ & - & $0.09-0.90$ & - & - & & 30 \\
\hline & $7^{\circ}$ & $0.3-0.6$ & $0.3-0.6$ & - & - & $0.3-1.1$ & $0.3-0.4$ & - & & 20 \\
\hline & 16 & $0.2-3.28$ & $0.2-1.78$ & $0.2-0.60$ & - & $0.2-1.02$ & - & - & $0.2-3.28$ & 28 \\
\hline $\begin{array}{l}\text { German sausage, } \\
\text { pate, non-smoked }\end{array}$ & 10 & $0.04-0.84$ & $0.02-7.5$ & $0.11-1.3$ & - & $0.09-0.41$ & $0.19-1.7$ & - & & 30 \\
\hline Sausage w/garlic & 2 & $0.04-1.3$ & $1.3-6.4$ & - & - & - & - & - & & 30 \\
\hline Sausage, salami type & 4 & $0.04-2.1$ & $1.5-12$ & $0.29-2.0$ & - & $0.09-0.58$ & - & - & & 30 \\
\hline Various smoked sausages & 15 & $0.04-9.3$ & $0.91-10.3$ & $0.11-2.0$ & $0.16-3.7$ & $0.09-2.2$ & $0.19-7.2$ & - & & 30 \\
\hline Smoked or dried Ham & 11 & $0.04-4.8$ & $0.06-12$ & $<0.11-1.1$ & - & $0.09-1.3$ & $0.19-2.0$ & - & & 30 \\
\hline \multirow{3}{*}{ Ham } & $2^{\#}$ & $0.18-0.23$ & ND & ND & ND & ND & ND-0.39 & ND & & $\$$ \\
\hline & 28 & $<0.2-3.45$ & $0.2-0.77$ & - & - & - & - & - & $0.2-3.45$ & 28 \\
\hline & 4 & $0.04-0.72$ & $0.06-0.07$ & $<0.11-0.23$ & $0.16-0.23$ & $0.09-0.97$ & - & - & & 30 \\
\hline \multirow{2}{*}{ Bacons } & $1^{\#}$ & $0.67-0.78$ & $0.17-0.19$ & ND & ND & ND & ND & ND & & $\$$ \\
\hline & $7^{\bullet}$ & $1.21-3.92$ & $0.2-0.77$ & - & - & $0.2-0.50$ & - & - & $0.2-3.92$ & 28 \\
\hline
\end{tabular}

ND: Not detected, -: Not tested, $¥:$ present study, ${ }^{\#}$ : number of composite samples, ${ }^{\bullet}$ : sample contained nitrite.

cessed meats, albeit in low concentration. Compared with the results reported by another research group, nitrosamine contents in the present study tended to be lower.

In oil samples, about $1 \mu \mathrm{g} / \mathrm{kg}$ of NDMA was detected on average. NDMA was detected in all of the samples and
NMOR was detected in soybean, olive, canola, rape, and sun follower oil; however, other nitrosamines were not detected (Table 9). Hedler and co-authors (25) reported 1 to $10 \mu \mathrm{g} / \mathrm{kg}$ of NDMA and NDEA in most edible oils. The present study showed similar results except for the fact that 
Table 9. N-nitrosamine contents in oils ( $\mu \mathrm{g} / \mathrm{kg})$

\begin{tabular}{|c|c|c|c|c|c|c|c|c|c|c|}
\hline Product & $\begin{array}{c}\text { Number of } \\
\text { samples }\end{array}$ & NDMA & NMEA & NDEA & NDBA & NPYR & NPIP & NMOR & Sum & Ref. \\
\hline \multirow{3}{*}{ Olive oil } & $2^{\#}$ & $0.98-1.5$ & ND & ND & ND & ND & ND & ND-0.49 & & + \\
\hline & 16 & $1.9-3.5$ & - & $1.7-3.6$ & - & - & - & - & & 25 \\
\hline & 12 & 0.51 (avg*) & - & 0.45 (avg) & ND & ND & ND & - & 0.96 & 26 \\
\hline \multirow{3}{*}{ Vegetable oil } & $7^{\#}$ & ND-2.39 & ND-0.16 & ND & ND & ND & ND-0.43 & ND & & 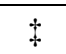 \\
\hline & 21 & $\begin{array}{c}23 \text { (highest), } \\
1-10\end{array}$ & - & $\begin{array}{c}21 \text { (highest) } \\
1.4 \text { (avg) }\end{array}$ & - & - & - & - & & 25 \\
\hline & 22 & $0.24-0.5$ & - & $0.18-0.24$ & ND & ND & ND & - & & 26 \\
\hline \multirow{2}{*}{ Grapeseed oil } & $2^{\#}$ & ND-1.12 & ND & ND & ND & ND & ND & ND-0.39 & & 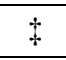 \\
\hline & 11 & 0.36 (avg) & - & 0.19 (avg) & ND & ND & ND & - & 0.55 & 26 \\
\hline \multirow{2}{*}{ Sunflower oil } & $2^{\#}$ & $1.01-2.83$ & ND & ND & ND & ND & ND & ND-0.7 & & + \\
\hline & 11 & 11 (highest) & - & 9.3 (avg) & - & - & - & - & & 25 \\
\hline Sunflower oil (refined) & 12 & 0.64 (avg) & - & 0.41 (avg) & ND & ND & ND & - & 1.05 & 26 \\
\hline Sunflower oil (not refined) & 10 & 0.71 (avg) & - & 0.47 (avg) & ND & ND & ND & - & 1.18 & 26 \\
\hline Perilla oil & $2^{\#}$ & $1.81-2.26$ & ND & $\mathrm{ND}$ & ND & ND & ND & ND & & 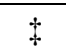 \\
\hline Sesame oil & $3^{\#}$ & $1.09-2.1$ & ND & ND & ND & ND & ND & ND & & + \\
\hline
\end{tabular}

${ }^{*}$ Avg: average. ND: Not detected, $-:$ Not tested, $\$$ : present study, ${ }^{\#}$ : number of composite samples.

Table 10. N-nitrosamine in butter and margarine $(\mu \mathrm{g} / \mathrm{kg})$

\begin{tabular}{|c|c|c|c|c|c|c|c|c|c|c|}
\hline Product & The number of samples & NDMA & NMEA & NDEA & NDBA & NPYR & NPIP & NMOR & Sum & Ref \\
\hline \multirow{2}{*}{ Margarine } & 14 & $0.2-0.3$ & - & - & - & - & - & $1.7-3.8$ & & 30 \\
\hline & 3 & $2.5-5.8$ & - & $1.4-5.5$ & - & - & - & - & & 25 \\
\hline Butter & 10 & - & - & - & - & - & - & 0.1 & & 30 \\
\hline
\end{tabular}

-: Not tested.

Table 11. N-nitrosamine in soybean paste, soy sauce, seasoning, and sauce $(\mu \mathrm{g} / \mathrm{kg})$

\begin{tabular}{|c|c|c|c|c|c|c|c|c|c|}
\hline Product & $\begin{array}{l}\text { The number } \\
\text { of samples }\end{array}$ & NDMA & NDEA & NDBA & NPYR & NPIP & NMOR & NMEA & Ref \\
\hline Market soy sauce & $1^{\#}$ & ND & $1.17-1.49$ & $0.13-0.19$ & $0.74-0.96$ & ND & ND & ND & $\ddagger$ \\
\hline Market soybean paste & $2^{\#}$ & ND-0.21 & ND-0.12 & ND-0.48 & ND & ND & ND & ND & + \\
\hline Sauce $^{\text {a) }}$ & $9^{\#}$ & ND-3.02 & ND-0.71 & ND-0.43 & ND-0.18 & ND & ND & ND & $\ddagger$ \\
\hline Seasoning $^{\mathrm{b})}$ & $5^{\#}$ & ND-13.48 & ND-1.01 & ND-1.88 & ND-6.48 & ND-6.53 & ND-0.21 & ND & $\ddagger$ \\
\hline Market soybean sauce & 1 & $1.1-2.7$ & - & - & - & - & - & - & 27 \\
\hline \multirow{3}{*}{ Traditional soy sauce } & $1^{\#}$ & ND & ND & ND & ND & ND & ND & ND & $t$ \\
\hline & 7 & - & - & - & $<0.02$ & $<0.01$ & - & - & 24 \\
\hline & 1 & $<0.5-1.87$ & - & - & - & - & - & - & 27 \\
\hline \multirow{2}{*}{ Market soybean paste } & 4 & - & - & - & $<0.02$ & $<0.01$ & - & - & 24 \\
\hline & 1 & $1.6-2.4$ & - & - & - & - & - & - & 27 \\
\hline \multirow{2}{*}{ Traditional soybean paste } & 7 & - & - & - & $<0.02$ & $<0.01$ & - & - & 24 \\
\hline & 1 & $1.5-3.1$ & - & - & - & - & - & - & 24 \\
\hline
\end{tabular}

ND: Not detected, -: Not tested, + : present study, $:$ number of composite samples.

${ }^{a)}$ Sauce samples included commercial sauce sold in market.

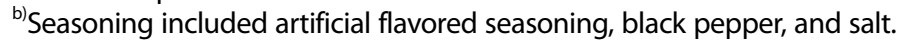


Table 12. N-nitrosamine contents in alcoholic beverages $(\mu \mathrm{g} / \mathrm{kg})$

\begin{tabular}{|c|c|c|c|c|c|c|c|c|c|}
\hline Product & $\begin{array}{l}\text { The number } \\
\text { of samples }\end{array}$ & NDMA & NDEA & NDBA & NPYR & NPIP & NMOR & NMEA & Ref \\
\hline \multirow{4}{*}{ Beer } & $3^{\#}$ & ND & ND & ND & ND & ND & ND & ND & $\ddagger$ \\
\hline & 12 & 0.28 & - & - & - & - & - & - & 30 \\
\hline & 6 & $0.5-1.87$ & - & - & - & - & - & - & 27 \\
\hline & 16 & - & $0.2-1.14$ & - & $0.2-0.84$ & - & $0.2-1.14$ & - & 28 \\
\hline Cognac, vodka & $1^{\#}$ & $0.02-0.2$ & - & - & - & - & - & - & 30 \\
\hline Wine & $3^{\#}$ & ND & ND & ND & ND & ND & ND & ND & $t$ \\
\hline Rice wine & $1^{\#}$ & ND & ND & ND & ND & ND & ND & ND & $\dagger$ \\
\hline \multirow{2}{*}{ Whisky } & $1^{\#}$ & $0.22-0.23$ & ND & ND & $0.3-0.39$ & ND & $0.16-0.24$ & ND & $\dagger$ \\
\hline & 2 & $0.68-2.5$ & - & - & - & - & - & - & 30 \\
\hline Malt beverage & 5 & - & $0.2-0.54$ & - & - & - & $0.2-0.73$ & - & 28 \\
\hline Other liquor $^{a)}$ & $5^{\#}$ & ND & ND & ND & ND & ND & ND & ND & $t$ \\
\hline
\end{tabular}

ND: Not detected, $-:$ Not tested, $\$$ : present study, ${ }^{\#}$ : number of composite samples.

${ }^{a}$ Other liquor included soju, white wine, refined rice wine, plum wine, raspberry wine, and fermented herb liquor.

NDEA was not detected in the present study. Yurchenko et al. (26) reported less than $0.71 \mu \mathrm{g} / \mathrm{kg}$ in all nitrosamines, but they used the method we have used in the fatless sample, which may not be sufficiently efficient to extract all nitrosamines from oils. Also, the method may not be able to remove the interference of remaining lipids for detection sensitivity. NDMA was also reported in margarine and butter, though the amount was low (Table 10) $(25,30)$.

The highest concentration of nitrosamines was observed in seasoning samples with $13.48 \mu \mathrm{g} / \mathrm{kg}$ of NDMA and $6.53 \mu \mathrm{g} / \mathrm{kg}$ of NPIP. Since previous studies on nitrosamines in seasoning are scarce, it needs to be investigated further concerning the formation mechanism in relation to the manufacturing process. In sauce samples, $3.02 \mu \mathrm{g} / \mathrm{kg}$ of NDMA was detected (Table 11).

In alcoholic beverages, no nitrosamine was detected in the present study in beer, wine, rice wine, soju, and other liquors, while trace amounts of NDMA, NPYR, and NMOR were detected in whisky. Kim et al. (27) reported the maximum of $1.87 \mu \mathrm{g} / \mathrm{kg}$ NDMA in beer (Table 12).

The analysis methods of nitrosamines have become more accurate and simple. From the 1960s, the nitrosamine analysis employed distillation (29). However, distillation could generate false results, since heat of the distillation procedure could facilitate the synthesis of nitrosamines; at the same time, low molecular weight nitrosamines could be lost during distillation due to the low vapor pressure. These days, various resins are used in the food analysis. In the present study, solid supported liquid extraction using Extrelut NT and Florisil SPE was employed (20). To analyze the whole spectrum of food items, the method had to be modified. For fatty foods, liquid-liquid extraction was used to extract polar organic nitrosamines from lipids. To speed up the extraction procedures, polar solvent, immiscible and lighter than oil, was searched. Acetone-water (3:1) mixture or acetone-acetonitrile mixture satisfied the terms. The extraction mixture was stored at $-80^{\circ} \mathrm{C}$ freezer to help the separation of the phases. Any remaining fat in the extract may interfere and damage analytical instrument. C-18 SPE cartridge laid with aluminum oxide powder was employed to remove the remaining fats and emulsifier. The final procedure can be used for food matrix with a large amount of fats and emulsifiers, such as dressings and creamers.

To estimate a close-to-real exposure of any hazardous compound, it is always better to analyze as many food items as possible; therefore, a fast and easy method is necessary. The methods reported in the present study can cover a wide range of food items on the Korean dining table and are also easy and fast. Our study also demonstrated the application of the methods to various food items, including agricultural, animal, and fishery products.

\section{ACKNOWLEDGEMENTS}

This study was supported by a grant (13162KFDA046) from Ministry of Food and Drug Safety in 2013-4.

\section{REFERENCES}

1. Scanlan, R.A. and Issenberg, P. (1975) N-nitrosamines in foods. CRC Crit. Rev. Food Sci. Nutr., 5, 357-402.

2. Cho, I. and Bratzler, L. (1970) Effect of sodium nitrite on flavor of cured pork. J. Food Sci., 35, 668-670.

3. Walker, R. (1990) Nitrates, nitrites and N-nitrosocompounds: a review of the occurrence in food and diet and the toxicological implications. Food Addit. Contam., 7, 717-768.

4. Rostkowska, K., Zwierz, K., Różański, A., Moniuszko-Jako- 
niuk, J. and Roszczenko, A. (1998) Formation and metabolism of N-Nitrosamines. Pol. J. Environ. Stud., 7, 321-325.

5. Gray, J.I. and Dugan, L.R. Jr. (1975) Inhibition of N-nitrosamine formation in model food systems. J. Food Sci., 40, 981984.

6. Douglass, M.L., Kabacoff, B.L., Anderson, G.A. and Cheng, M.C. (1978) The chemistry of nitrosamine formation, inhibition and destruction. J. Soc. Cosmet. Chem., 29, 581-606.

7. Mirvish, S.S., Wallcave, L., Eagen, M. and Shubik, P. (1972) Ascorbate-nitrite reaction: possible means of blocking the formation of carcinogenic N-nitroso compounds. Science, 177, 65-68.

8. Sen, N.P., Smith, D.C. and Schwinghamer, L. (1969) Formation of $\mathrm{N}$-nitrosamines from secondary amines and nitrite in human and animal gastric juice. Food Cosmet. Toxicol., 7, 301-307.

9. O'Brien, T.J., Lukes, B.K. and Scanlan, R.A. (1980) Control of N-nitrosodimethylamine in malt through the use of liquid/ gaseous sulfur dioxide. MBAA TQ, 17, 196-200.

10. Smith, N.A. (1994) Cambridge prize lecture nitrate reduction and N-nitrosamines in brewing. J. Inst. Brew., 100, 347-355.

11. Mah, J.H., No, H.K., Kim, Y.J. and Hwang, H.J. (2004) Determination of biogenic amines in kimchi, Korean traditional fermented vegetable products. Food Sci. Biotechnol., 6, 826-829.

12. Choi, J. and Valentine, R.L. (2002) Formation of N-nitrosodimethylamine (NDMA) from reaction of monochloramine: a new disinfection by-product. Water Res., 36, 817-824.

13. Walters, C.L., Downes, M.J., Edwards, M.W. and Smith, P.L. (1978) Determination of a non-volatile N-nitrosamine on a food matrix. Analyst, 103, 1127-1133.

14. International Agency for Research on Cancer. (2014) Agents classified by the IARC monographs. IARC, 1-111, pp. 1-35.

15. Li, L., Wang, P., Xu, X. and Zhou, G. (2012) Influence of various cooking methods on the concentrations of volatile Nnitrosamines and biogenic amines in dry-cured sausages. $J$. Food Sci., 77, C560-C565.

16. Pensabene, J.W., Fiddler, W., Gates, R.A., Fagan, J.C. and Wasserman, A.E. (1974) Effect of frying and other cooking conditions on nitrosopyrrolidine formation in bacon. J. Food Sci., 39, 314-316.

17. Mottram, D.S., Patterson, R.L., Edwards, R.A. and Gough, T.A. (1977) The preferential formation of volatile N-nitrosamines in the fat of fried bacon. J. Sci. Food Agric., 28, 10251029.

18. Fiddler, W., Pensabene, J.W., Kushnir, I. and Piotrowski, E.G. (1973) Effect of frankfurter cure ingredients on N-nitrosodimethylamine formation in a model system. J. Food Sci., 38, 714-715.

19. Seo, J.E., Park, J.E., Lee, J.Y. and Kwon, H. (2015) Determination of seven $\mathrm{N}$-nitrosamines in agricultural food matrices using GC-PCI-MS/MS. Food Anal. Methods, submitted.

20. Raoul, S., Gremaud, E., Biaudet, H. and Turesky, R.J. (1997)
Rapid solid-phase extraction method for the detection of volatile nitrosamines in food. J. Agric. Food Chem., 45, 47064713.

21. Myeong, S.W. (2011) Study on guideline development for method validation. KFDA final report project No. 11182KFDA673. Accessed November 30, 2011.

22. Kim, B.Y. and Yoon, S. (2003) Analysis of nitrate contents of Korean common foods. Food Sci. Biotechnol., 32, 779-784.

23. Kim, K.R., Shin, J.H., Lee, S.J., Kang, H.H., Kim, H.S. and Sung, N.J. (2002) The formation of N-nitrosamine in kimchi and salt-fermented fish under simulated gastric digestion. $J$. Food Hyg. Saf., 17, 94-100.

24. KFDA. (2009) Study on establishment of specification and analytical method for nitrosamines in rubber food contact materials. KFDA final report project No. 09071KFDA008. Accessed December 31, 2009.

25. Hedler, L., Schurr, C. and Marquardt, P. (1979) Determination of volatile $\mathrm{N}$-nitroso compounds in various samples of edible vegetable oils and margarine (commercially available products). J. Am. Oil Chem. Soc., 56, 681-684.

26. Yurchenko, S. and Mölder, U. (2005) The determination of polycyclic aromatic hydrocarbons in smoked fish by gas chromatography mass spectrometry with positive-ion chemical ionization. J. Food Compos. Anal., 18, 857-869.

27. Kim, K.R., Lee, S.J., Shin, J.H., Seo, J.K., Shon, M.Y. and Sung, N.J. (2002) The formation of N-nitrosamine in soy sauce, soybean paste and beer under simulated gastric digestion. J. Korean Soc. Food Sci. Nutr., 31, 378-383.

28. Jo, C.H., Park, H.R., Kim, D.S., Lee, K.H. and Kim, M.H. (2010) Exposure assessment of N-nitrosamines in foods. Food Sci. Biotechnol., 5, 541-548.

29. Sen, N.P. and Seaman, S. (1981) Investigation into the possible presence of volatile $\mathrm{N}$-nitrosamines in cooking oils, margarine, and butter. J. Agric. Food Chem., 29, 787-789.

30. Mavelle, T., Bouchikhi, B. and Debry, G. (1991) The occurrence of volatile N-nitrosamines in French foodstuffs. Food Chem., 42, 321-338.

31. Okafor, P.N. and Nwogbo, E. (2005) Determination of nitrate, nitrite, $\mathrm{N}$-nitrosamines, cyanide and ascorbic acid contents of fruit juices marketed in Nigeria. Afr. J. Biotechnol., 4, 11051108.

31. Zou, X., Li, J., Lu, S., Song, X., Wang, X., Guo, L., Li, J. and Ye, J. (1992) Volatile N-nitrosamines in salted fish samples from high-and low-risk areas for NPC in China. Chin. Med. Sci. J., 7, 201-204.

32. Oliveira, C.P., Gloria, M.B.A., Barbour, J.F. and Scanlan, R.A. (1995) Nitrate, nitrite, and volatile nitrosamines in whey-containing food products. J. Agric. Food Chem., 43, 967-969.

33. Scanlan, R.A., Barbour, J.F., Hotchkiss, J.H. and Libbey, L.M. (1980) N-nitrosodimethylamine in beer. Food Cosmet. Toxicol., 18, 27-29. 